\title{
Methanol-Based Chain Elongation with Acetate to $n$-Butyrate and Isobutyrate at Varying Selectivities Dependent on pH
}

\author{
Kasper D. de Leeuw, Sanne M. de Smit, Sabine van Oossanen, Marinus J. Moerland, Cees J. N. Buisman,
} and David P. B. T. B. Strik*

Cite This: ACS Sustainable Chem. Eng. 2020, 8, 8184-8194

Read Online

\section{ACCESS | Lill Metrics \& More | 回 Article Recommendations | (1) Supporting Information}

ABSTRACT: Biomass fermentation technologies offer alternative methods to produce platform chemicals that currently originate from fossil sources. This research showed that an enriched microbiome was capable to produce isobutyrate $\left(\mathrm{i}-\mathrm{C}_{4}\right)$ from acetate via methanol-based chain elongation. A long-term continuous reactor experiment showed that the selectivity for $\mathrm{i}-\mathrm{C}_{4}$ and/or n-butyrate $\left(n-C_{4}\right)$ could be reversibly adjusted by changing the reactor $\mathrm{pH}$. A reactor $\mathrm{pH}$ of 6.75 led to formation of (carbon per total carbon of products) $0.78 \mathrm{n}-\mathrm{C}_{4}$ and $0.024 \mathrm{i}-\mathrm{C}_{4}$, whereas a reactor $\mathrm{pH}$ of 5.2 led to a selectivity of $0.24 \mathrm{n}-\mathrm{C}_{4}$ and $0.65 \mathrm{i}-\mathrm{C}_{4}$. This shift in product spectrum was also represented by a shift in microbial composition. The results suggest that a Eubacterium genus is responsible for the formation of $\mathrm{n}-\mathrm{C}_{4}$, whereas a Clostridium luticellarii strain is responsible for the formation of a mixture of $i-C_{4}$ and $n-C_{4}$. The formation of $n-C_{4}$ and $i-C_{4}$ at a low $\mathrm{pH}$ was observed to be coupled according to the thermodynamics of

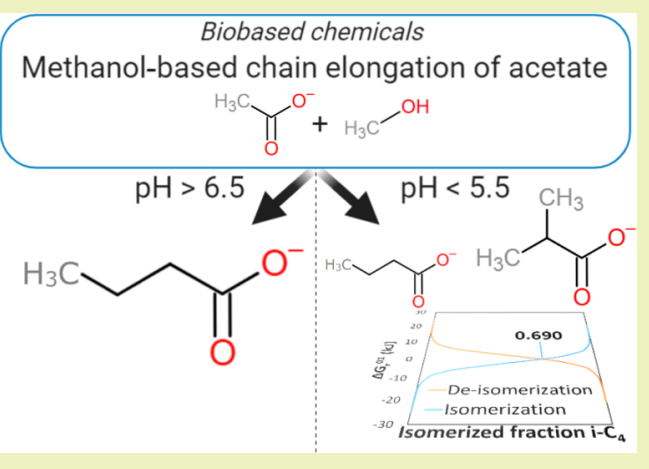
isomerization. At a reactor $\mathrm{pH}$ of 5.5 and 5.2 , the product ratio of $\mathrm{i}-\mathrm{C}_{4}: \mathrm{n}-\mathrm{C}_{4}$ approached $0.69 \mathrm{i}-\mathrm{C}_{4}: 0.31 \mathrm{n}-\mathrm{C}_{4}$, which is the theoretical ratio that would be achieved when determined by the equilibrium of isomerization. Various batch experiments at $\mathrm{pH} 5.5$ and 5.2 confirmed that addition of either $n-C_{4}$ or $i-C_{4}$ at the start of the batch would directly lead to the formation of the other butyrate component. Moreover, batch experiments performed at $\mathrm{pH} 6.5$ produced mainly $\mathrm{n}-\mathrm{C}_{4}$ and led to the development of a completely different microbiome. The imposed $\mathrm{pH}$ is a strong selection pressure that can facilitate changes in product selectivities for $\mathrm{n}-\mathrm{C}_{4}$ and $\mathrm{i}-\mathrm{C}_{4}$ during methanol-based chain elongation of acetate.

KEYWORDS: Chain elongation, Selection pressure, Open-culture fermentation, Biobased chemicals, Methanol, n-Butyrate, Isobutyrate

\section{INTRODUCTION}

The necessity to transition toward a circular economy has driven researchers to explore new biomass fermentation processes for alternative production of currently oil-derived and palm-derived chemicals. ${ }^{1-4}$ Microbial chain elongation fermentations have potential to become alternative and sustainable technologies for acquiring platform chemicals, such as short chain carboxylates (SCCs) and medium chain carboxylates (MCCs). ${ }^{5-7}$ Biomass residues and $\mathrm{CO}_{2}$ are used as favorable substrates for these bioprocesses. The carbon streams can be more efficiently recycled which could help lessen environmental harmful expansion of agricultural areas. Microbiomes that catalyze chain elongation processes have been enriched using different selection pressures, for which the electron donor is an important factor. ${ }^{4,8}$ Methanol is an exceptionally interesting electron donor, because it can be electrochemically synthesized from $\mathrm{CO}_{2}$ or thermochemically produced from lignocellulosic biomass. ${ }^{9-12}$

Recently it has been shown that isobutyrate $\left(\mathrm{i}-\mathrm{C}_{4}\right)$ can be formed during methanol-based microbial chain elongation. ${ }^{13,14}$ It was observed that a high concentration of n-butyrate $\left(n-C_{4}\right)$ is necessary to stimulate isomerization toward $\mathrm{i}-\mathrm{C}_{4}$ within the methanol-based chain elongation microbiome. It was also shown that addition of methanol to $\mathrm{n}-\mathrm{C}_{4}$-rich fermented supermarket waste residue induced the formation of $\mathrm{i}-\mathrm{C}_{4}$. The precise metabolic route for the biochemical $\mathrm{i}-\mathrm{C}_{4}$ formation has not been fully elucidated, but it was suggested that it takes place via methanol chain elongation and subsequent isomerization of $\mathrm{n}-\mathrm{C}_{4}$ to $\mathrm{i}-\mathrm{C}_{4}$. Alternatively $\mathrm{i}-\mathrm{C}_{4}$ can be formed via microbial electrosynthesis; however, for now, its formation was only observed as a side product. ${ }^{15,16}$ Also biological production of $\mathrm{i}-\mathrm{C}_{4}$ from sugars has been shown using metabolically engineered strains. ${ }^{17,18}$ Currently, $\mathrm{i}-\mathrm{C}_{4}$ is produced chemically from fossil-based feedstocks and other compounds such as alkali metal bases or metal alcoholates. ${ }^{19}$ Isobutyrate can be used in the production processes of transparent thermoplastics, emulsifiers, vitamins, antibiotics, and organic solvents. ${ }^{17,20,21}$ It

Received: February 4, 2020

Revised: March 30, 2020

Published: May 27, 2020 
has a market size of around $2.7 \times 10^{6}$ ton/year. ${ }^{18}$ The newly discovered methanol chain elongation bioprocess within a mixed culture is a prospective alternative route toward $\mathrm{i}-\mathrm{C}_{4}$ production. ${ }^{13}$ By using only acetate and methanol as sole substrates and by using a mixed culture, a versatile organic residue-based fermentation process can be developed. ${ }^{22}$ Methanol-based chain elongation experimentally complied to the following stoichiometry (eq 1) $13,23,24$

$$
\begin{aligned}
& 2 \text { methanol }+ \text { acetate } \rightarrow \text { n-butyrate }+2 \mathrm{H}_{2} \mathrm{O} \\
& \Delta G_{\mathrm{r}}{ }^{01}=-106.8 \mathrm{~kJ}
\end{aligned}
$$

The objectives of this study were to further elucidate the selection pressure involved in enriching the $\mathrm{i}-\mathrm{C}_{4}$ forming microbiome and to develop this microbiome without supplying exogenous $n-C_{4}$. A long-term continuous reactor system was operated in order to study varying $\mathrm{pH}$ levels (from 6.75 to 5.2). The necessity for high $\mathrm{n}-\mathrm{C}_{4}$ concentrations in earlier studies was hypothesized as a toxic effect on the microbiome that induced isomerization. ${ }^{13}$ Hypothetically, a similar selection pressure could be achieved by high amounts of in situ butyrate formation from acetate and methanol. Additionally, lowering the $\mathrm{pH}$ and thus increasing the amount of undissociated acids in the broth could further amplify the toxicity of the formed butyrates toward microorganisms. ${ }^{25,26}$ We show with this experimental work that at $\mathrm{pH} 5.2$ the microbiome produced $\mathrm{i}-\mathrm{C}_{4}$ with a $65 \%$ carbon selectivity from acetate and methanol as sole substrates. A selection pressure tool is presented that can be used to form $\mathrm{i}-\mathrm{C}_{4}$ with a mixed culture from simple molecules such as acetate and methanol.

In addition to the continuous reactor experiment, a series of batch experiments was done to gain insight into the microbial activity and microbiome enrichment under varying starting $\mathrm{pH}$ levels, different $\mathrm{n}-/ \mathrm{i}-\mathrm{C}_{4}$ starting concentrations, and different substrate (acetate and methanol) concentrations. These batch series give insight into how the $\mathrm{i}-\mathrm{C}_{4}$ production is coupled to catabolic conversion of the chain elongation substrates and how the isomer formation specificity is affected.

\section{MATERIALS AND METHODS}

This research aimed to investigate what selection pressure is needed for a methanol chain elongation microbiome to produce isobutyrate $\left(\mathrm{i}-\mathrm{C}_{4}\right)$ and/or n-butyrate $\left(\mathrm{n}-\mathrm{C}_{4}\right)$ from acetate $\left(\mathrm{C}_{2}\right)$ and methanol $(\mathrm{MeOH})$. A continuous reactor was operated throughout seven phases to investigate the effect of different $\mathrm{pH}$ levels ( $\mathrm{pH}$ 5.2, 5.5, 6.0, and 6.75). Moreover, $\mathrm{CO}_{2}$ addition was removed (phase I $\rightarrow$ II). A slight increase and consecutive decrease of acetate in the influent were executed (II $\rightarrow$ III $\rightarrow$ IV), and the vitamin B12 supply was dropped by a factor of 30 (III $\rightarrow$ IV). A description of the operating conditions during the seven phases is shown in Table 1 . The reactor system was characterized by analysis of the steady state mass balances for the total amount of carbon and electrons in the liquid and gas phases.

In addition to the continuous reactor, batch experiments were performed to investigate (i) the immediate effect of two different $\mathrm{pH}$ levels (5.2 and 6.5) on product formation and microbial composition,

(ii) whether initial $\mathrm{n}-\mathrm{C}_{4}$ or i- $\mathrm{C}_{4}$ addition affects the product selectivity,

(iii) how the absence or presence of carbon sources affect the (de)isomerization of $\mathrm{n}-\mathrm{C}_{4}$ and $\mathrm{i}-\mathrm{C}_{4}$, and (iv) how different substrate concentrations affect the methanol chain elongation process. An overview of the batch experiments is given in Table 2 .

Medium. The synthetic growth medium contained the following macronutrients $\left(\mathrm{g} \mathrm{L}^{-1}\right): \mathrm{NH}_{4} \mathrm{H}_{2} \mathrm{PO}_{4}, 3.60 ; \mathrm{MgCl}_{2} \cdot 6 \mathrm{H}_{2} \mathrm{O}, 0.33$; $\mathrm{MgSO}_{4} \cdot 7 \mathrm{H}_{2} \mathrm{O}, 0.20 ; \mathrm{CaCl}_{2} \cdot 2 \mathrm{H}_{2} \mathrm{O}, 0.20 ; \mathrm{KCl}, 0.20$, and yeast extract, 1.0. Micronutrients were used as described in Phillips et al. (designed basal medium, Pfennig trace metals, and B-vitamins). ${ }^{27}$ The B-vitamin

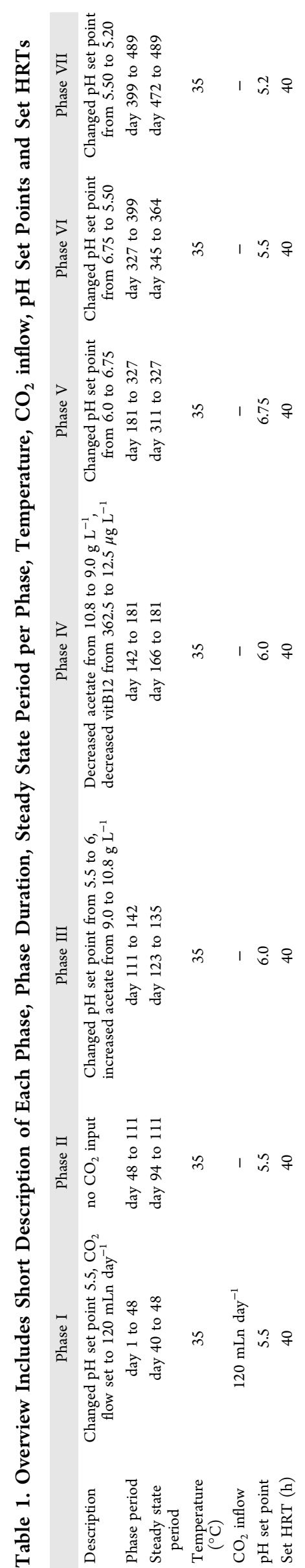


Table 2. Overview of Performed Batches

\begin{tabular}{|c|c|c|c|c|c|c|}
\hline Inoculum & $\begin{array}{l}\text { Methanol, } \\
\mathrm{mM}\end{array}$ & $\begin{array}{c}\text { Acetate } \\
(\mathrm{mM})\end{array}$ & $\mathrm{pH}$ & $\begin{array}{l}\mathrm{i}-\mathrm{C}_{4} \\
(\mathrm{mM})\end{array}$ & $\begin{array}{l}\mathrm{n}-\mathrm{C}_{4} \\
(\mathrm{mM})\end{array}$ & $\begin{array}{l}\text { Batch } \\
\text { code }\end{array}$ \\
\hline \multirow{4}{*}{$\begin{array}{c}\text { Phase VII } \\
\text { (suspended cells) }\end{array}$} & 50 & 25 & 5.2 & & 50 & I \\
\hline & 50 & 25 & 6.5 & & 50 & II \\
\hline & 50 & 25 & 5.2 & 50 & & III \\
\hline & 50 & 25 & 6.5 & 50 & & IV \\
\hline \multirow{4}{*}{$\begin{array}{l}\text { Phase VII } \\
\text { (suspended cells) }\end{array}$} & - & - & 5.2 & & 50 & $\mathrm{~V}$ \\
\hline & - & - & 6.5 & & 50 & VI \\
\hline & - & - & 5.2 & 50 & & VII \\
\hline & - & - & 6.5 & 50 & & VIII \\
\hline \multirow{4}{*}{$\begin{array}{l}\text { Repeated batch } \\
\text { (suspended cells) }\end{array}$} & 300 & 150 & 5.5 & 0 & - & A \\
\hline & 300 & 150 & 5.5 & 5 & - & B \\
\hline & 300 & 150 & 5.5 & 20 & - & $\mathrm{C}$ \\
\hline & 300 & 150 & 5.5 & 50 & - & $\mathrm{D}$ \\
\hline none & 300 & 150 & 5.5 & 0 & - & $\mathrm{E}$ \\
\hline $\begin{array}{l}\text { Repeated batch } \\
\text { (suspended cells) }\end{array}$ & 0 & 0 & 5.5 & 0 & - & F \\
\hline \multirow{6}{*}{$\begin{array}{l}\text { Repeated batch } \\
\text { (suspended cells) }\end{array}$} & 50 & 25 & 5.5 & 50 & - & G \\
\hline & 100 & 50 & 5.5 & 50 & - & $\mathrm{H}$ \\
\hline & 200 & 200 & 5.5 & 50 & - & $\mathrm{J}$ \\
\hline & 300 & 150 & 5.5 & 50 & - & $\mathrm{K}$ \\
\hline & 50 & 25 & 5.2 & 50 & - & $\begin{array}{l}\mathrm{L}(\mathrm{III} \\
\text { repeat })\end{array}$ \\
\hline & 0 & 0 & 5.5 & 50 & - & $\mathrm{M}$ \\
\hline $\begin{array}{c}\text { Eubacterium } \\
\text { limosum }\end{array}$ & 300 & 150 & 5.5 & - & - & EL batch \\
\hline
\end{tabular}

composition of this medium differed in phases I, II, and III. The vitamin $B_{12}$ cobalamin concentration in these phases was 30 times higher than in the following phases $\left(0.375 \mathrm{mg} \mathrm{L}^{-1}\right.$ compared to $0.0125 \mathrm{mg} \mathrm{L}^{-1}$ ). The higher vitamin concentration was initially used in concordance to the earlier done research on methanol-based formation $\mathrm{i}-\mathrm{C}_{4} \cdot{ }^{13}$ The vitamin concentration was lowered in order to rule out the necessity of these high amounts. The carbon sources during the whole study were acetate and methanol. For the continuous reactor experiment in phases I, II, IV, V, VI, and VII, the concentrations were $150 \mathrm{mM}\left(8.9 \mathrm{~g} \mathrm{~L}^{-1}\right)$ acetate and $300 \mathrm{mM}$ $\left(9.6 \mathrm{~g} \mathrm{~L}^{-1}\right)$ methanol, and during phase III, the acetate concentration was temporarily increased to $180 \mathrm{mM}\left(10.8 \mathrm{~g} \mathrm{~L}^{-1}\right)$. The starting concentrations for the batch experiments ranged from 50 and $25 \mathrm{mM}$ to, respectively, 300 and $200 \mathrm{mM}$ for methanol and acetate (see Table 2 for the exact starting concentrations for each batch).

Inoculum. The reactor was inoculated with an undefined anaerobic culture that originated from a reactor that performed methanol chain elongation from $\mathrm{n}-\mathrm{C}_{4}$ to $\mathrm{n}$-caproate and also formed $\mathrm{i}$ $\mathrm{C}_{4} \cdot{ }^{13} \mathrm{~A}$ complete $1 \mathrm{~L}$ broth was used at the start of this experiment. The batches of the first series (I-VIII, Table 2) were inoculated with suspended biomass from the continuous reactor during the end of phase VII. The batches of the second series were inoculated with biomass that originated from batch III and was subsequently kept active with a repeated batch. A more detailed description of the inoculation is described in the Supporting Information, Materials and Methods.

Reactor Setup and Operation. The reactor experiment was performed for 489 days in a lab-scale continuous up flow anaerobic reactor setup ( $1 \mathrm{~L}$ working volume) as described in an earlier chain elongation research. ${ }^{28}$ Table 1 summarizes the operating parameters (HRT, $\mathrm{pH}, \mathrm{CO}_{2}$ ). The temperature was kept constant at $35^{\circ} \mathrm{C}$. The medium inflow was set at $25 \mathrm{~mL} \mathrm{~h}^{-1}$, which led to an HRT of around 40-46 h. During the first four phases, the HRT slowly increased due to diminished flow rate caused by clogging of the influent tubes. This problem was solved from phase $\mathrm{V}$ and onward. The aim of the chosen HRT value was to provide sufficient retention for methanol-based chain elongation organisms, while simultaneously suppressing suspended methanogenic growth., ${ }^{9,2}$ Biofilms were allowed to grow in the reactor; periodically (approximately once per month), sludgelike biomass that accumulated in the $\mathrm{pH}$ control unit was removed. The reactor $\mathrm{pH}$ was regulated by automatic titration using $1 \mathrm{M} \mathrm{KOH}$ as the base. In the first phase, $\left(120 \mathrm{mLn} \mathrm{day}^{-1}\right) \mathrm{CO}_{2}$ was supplied, because earlier experiments showed successful methanol-based chain elongation under $\mathrm{CO}_{2}$ supplementation. ${ }^{9,23}$ However, $\mathrm{CO}_{2}$ can act as electron acceptor for acetate-producing methylotrophs which compete for methanol as the substrate and reduce selectivity toward butyrates. ${ }^{24}$ Additionally, sufficient $\mathrm{CO}_{2}$ was produced in the reactor itself, via possibly yeast extract conversion and/or methanogenesis. Therefore, its supply was stopped from phase II and onward. The reactor was partially mixed via internal recirculation at $150 \mathrm{~mL} \mathrm{~min}^{-1}$. A schematic overview of the reactor setup is shown in Figure S1.

Steady State Characterization. During the seven phases, a steady state was assumed when the following criteria were met: (i) For at least five times, the HRT no setup change had occurred. (ii) Main metabolite concentrations and corresponding conversion rates were relatively constant. Relatively constant is defined as when the confidence interval was less than $20 \%$ of the steady state average values. Confidence intervals were determined with an $\alpha$ of 0.01 and are indicated with a \pm .

Batch Experiments. At the end of the seventh phase, a series of eight batch experiments was carried out in duplo to investigate how the formation of $n-C_{4}$ and i- $C_{4}$ is coupled to methanol-based acetate elongation under various conditions (Table 2).

First, batches were performed at $\mathrm{pH} 6.5$ (batches II, IV, VI, and VIII) and at pH 5.2 (batches I, III, V, and VII). Second, the effect of initially present chain elongation products on formation selectivity was investigated: either $50 \mathrm{mM} \mathrm{n}-\mathrm{C}_{4}$ (batches I, II, V, and VI) or 50 $\mathrm{mM} \mathrm{i}^{-\mathrm{C}_{4}}$ (batches III, IV, VII, and VIII) was added. Third (V to III), a control series was performed without methanol and acetate in the medium, because it was unclear if $\mathrm{i}-\mathrm{C}_{4}$ was formed via a secondary isomerization coupled to degradation ${ }^{30-34}$ or via a catabolically (and seemingly irreversible) driven formation. After this first series, the microbiome from batch III was used for a second series of 12 batch experiments in duplicate (batches A to $\mathrm{M}$, Table 2) to determine how different substrate concentrations affect the methanol-based chain elongation. In addition to these batches, a pure culture Eubacterium limosum 2A (DSM 2593) was used as inoculum to perform a batch at pH 5.5 and methanol and acetate as substrates. The aim was to check if this culture was able to also form $\mathrm{i}-\mathrm{C}_{4}$ under these conditions, as it is known that E. limosum can form $\mathrm{n}-\mathrm{C}_{4}{ }^{35}$ The protocols for the batch experiments are described in the Supporting Information, Materials and Methods, and Tables S1-S6.

Sampling and Measurement. Continuous reactor samples were taken approximately two or three times per week. Batch samples were taken three times per week in the beginning and less frequently as the batch progressed. The $\mathrm{pH}$ of the samples was checked using an external $\mathrm{pH}$ meter, which allowed periodic recalibration of the internal $\mathrm{pH}$ controller in the continuous system. The liquid samples were analyzed for primary alcohols (methanol to hexanol), isobutanol, and volatile fatty acids (acetic acid to $\mathrm{n}$-caprylic acid) composition via gas chromatography by an earlier described method. ${ }^{36}$ The headspace gas was analyzed every time a liquid sample was taken. The concentrations of $\mathrm{O}_{2}, \mathrm{~N}_{2}, \mathrm{CH}_{4}, \mathrm{H}_{2}$, and $\mathrm{CO}_{2}$ were determined via two gas chromatography systems as described earlier. ${ }^{7,9}$ The headspace of the continuous reactor was connected to a gas meter ( $\mu$ Flow Bioprocess Control, Sweden) to measure gas production. The headspace pressure in the batches was measured (pressure meter GMH 3151).

Microbial Community Analysis. Biomass samples during the steady states in phases II, IV, V, VI, and VII, as well as biomass samples taken at the end of batches (I to VIII) were used to analyze the microbial compositions. Biomass was acquired by spinning down approximately $25 \mathrm{~mL}$ of suspended broth (either from the continuous reactor or at the end of a batch run) and subsequently snap freezing 


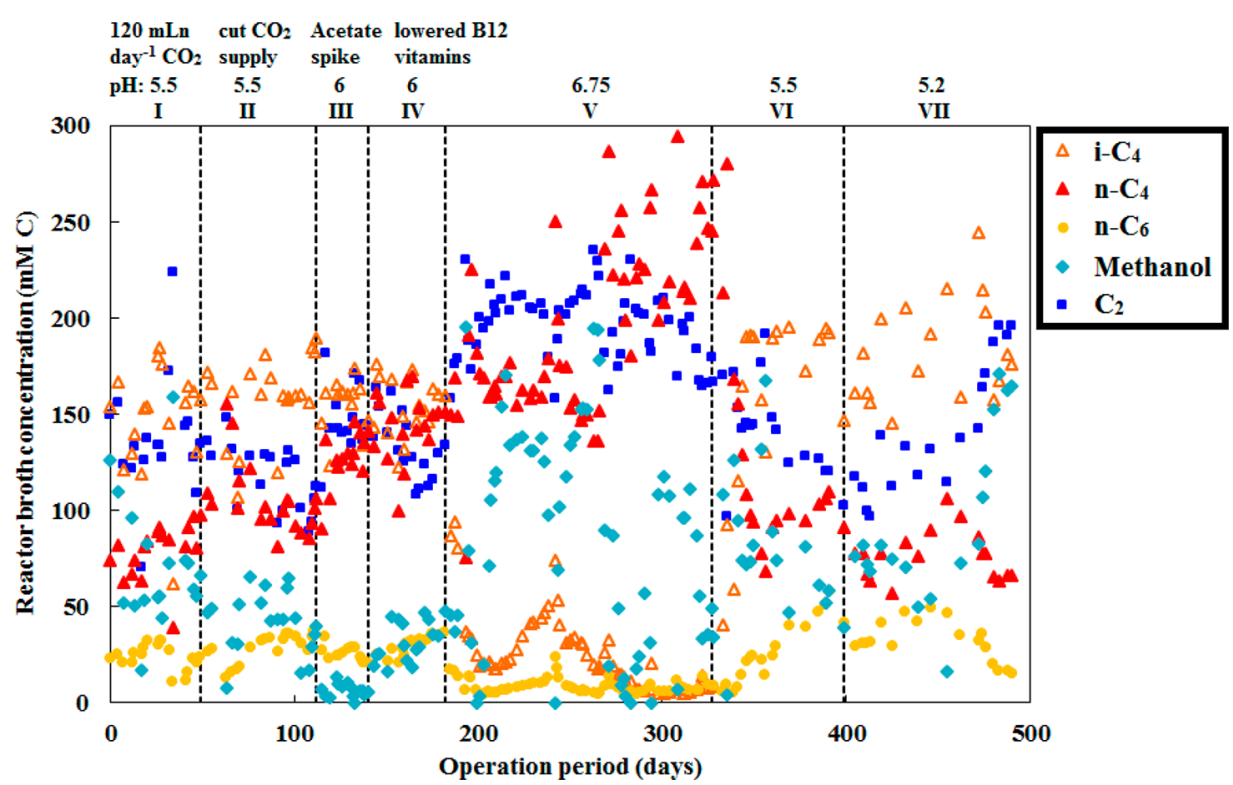

Figure 1. Graph shows the reactor broth concentrations of the main metabolites. A short summary of each phase is depicted above the graph. For phase VII, the $\mathrm{pH}$ set point value 5.2 was stably maintained only for the last 50 days (10 measurement points) due to $\mathrm{pH}$ probe calibration issues.

the pellet using liquid nitrogen and storing it at $-80^{\circ} \mathrm{C}$. In the case of the biofilm sample in phase VI, $1 \mathrm{~mL}$ of biomass sludge was used for the DNA extraction. All biomass samples were taken in duplo and analyzed separately. DNA was extracted using a Powersoil DNA isolation kit. The isolated DNA was used as a template for amplifying the V3-V4 region of the 16S rRNA gene using the illumina library generation method described by Takahashi et al. ${ }^{37}$ Exactly the same method for the 16s rRNA gene analysis was used as described earlier. ${ }^{28,38-40}$ Sequences of frequently found OTUs were used for a NCBI BLAST query. Canoco 5 was used to make two redundancy triplots (Figures S21 and S22) to support discussed correlations. Sequencing data are submitted to the ENA database and can be found with the accession number PRJEB36205.

\section{RESULTS}

Reactor $\mathrm{pH}$ Influences Formation Selectivities of $\mathrm{n}-\mathrm{C}_{4}$ and $\mathrm{i}-\mathrm{C}_{4}$ during Methanol-Based Chain Elongation of Acetate. The continuous reactor system enriched microbiomes that performed methanol-based chain elongation of acetate $\left(C_{2}\right)$ to isobutyrate $\left(i-C_{4}\right)$ and n-butyrate $\left(n-C_{4}\right)$ as main products in varying ratios dependent on reactor $\mathrm{pH}$. Side products were $\mathrm{n}$-caproate $\left(\mathrm{n}-\mathrm{C}_{6}\right)$ and methane $\left(\mathrm{CH}_{4}\right)$. Figure 1 shows the reactor broth concentrations of the main metabolites, and Table 3 summarizes the performance of the reactor. The results from phases IV to VII are particularly important because the only varied reactor parameter in the phases following phase IV was the broth $\mathrm{pH}$. During the shift from phase IV to $\mathrm{V}$, it took around 100 days for the $\mathrm{i}-\mathrm{C}_{4}$ formation rate to drop and stabilize at around $4 \mathrm{mmol} \mathrm{C} \mathrm{L}^{-1}$ day $^{-1}$. Consequently, $\mathrm{n}-\mathrm{C}_{4}$ formation increased with $86 \%$ to $142 \pm 13 \mathrm{mmol} \mathrm{C} \mathrm{L}^{-1} \mathrm{day}^{-1}$ or $3.1 \pm 0.3 \mathrm{~g} \mathrm{~L}^{-1} \mathrm{day}^{-1}$. With a concentration of $237 \pm 22 \mathrm{mM} \mathrm{C}$ or $5.2 \pm 0.5 \mathrm{~g} \mathrm{~L}^{-1}, \mathrm{n}^{-C_{4}}$ was the dominant product in phase $\mathrm{V}(78 \%$ selectivity based on carbon atoms). The reactor $\mathrm{pH}$ set point was lowered to $\mathrm{pH}$ 5.5 in phase $\mathrm{VI}$ in order to investigate the reversibility of using $\mathrm{pH}$ as a selection pressure to enrich an $\mathrm{i}-\mathrm{C}_{4}$ forming microbiome. It took 18 days (about 11 times the HRT) for the $\mathrm{i}-\mathrm{C}_{4}$ formation rate to return back to the levels achieved in phases I and II. In the last phase (VII), the $\mathrm{pH}$ set point was set to 5.2. This led to the highest achieved steady state average volumetric production rate for $\mathrm{i}-\mathrm{C}_{4}$, with $111 \pm 15 \mathrm{mmol} \mathrm{C}$ $\mathrm{L}^{-1} \mathrm{day}^{-1}$ or $2.4 \pm 0.3 \mathrm{~g} \mathrm{~L}^{-1} \mathrm{day}^{-1}$, an average broth concentration of $191 \pm 28 \mathrm{mM} \mathrm{C}$ or $4.2 \pm 0.6 \mathrm{~g} \mathrm{~L}^{-1}$, and $65 \%$ selectivity (based on carbon atoms).

Methanogenic Activity Was Strongly Sensitive to Change between pH 5.6 and 5.2. From day 374 in phase VI to day 455 in phase VII, there were calibration issues of the automatic titration setup that led to increased hydroxide dosage and subsequently to a broth $\mathrm{pH}$ that was higher than the set point (Figure S4). As a result, prior to the steady state in phase VII (at $\mathrm{pH} 5.23 \pm 0.07$ ), the $\mathrm{pH}$ rose slowly from $\mathrm{pH}$ 5.24 up to 5.64 on day 455 . An increase and decrease in methane formation rate were observed concomitant with this $\mathrm{pH}$ rise and fall (Figure S4). During the steady state of phase VII, the average methane formation rate had dropped by $90 \%$ compared to the steady state value in phase VI (at pH $5.61 \pm$ $0.06)$. The $\mathrm{i}-\mathrm{C}_{4}$ formation rate and concentration did not change significantly compared to phase VI, whereas the $\mathrm{n}-\mathrm{C}_{4}$ formation rate had dropped by $20 \%$.

Cutting $\mathrm{CO}_{2}$ Supply (II) and Reducing Vitamin B12 Feed (IV) Did Not Adversely Affect Chain Elongation Performance. In the second phase, the $\mathrm{CO}_{2}$ addition was ceased, which led to a $26 \%$ decrease in $\mathrm{CH}_{4}$ formation and a $47 \%$ increase in $\mathrm{n}-\mathrm{C}_{6}$ formation. The steady state average $\mathrm{CO}_{2}$ partial pressure did drop from $23.7 \pm 1.4$ (phase I) to $17.2 \pm$ $1.3 \mathrm{kPa}$ (phase II). Gas headspace partial pressures are shown in Figure S5. Conversion of the main metabolites (substrates $\mathrm{MeOH}, \mathrm{C}_{2}$ and products $\mathrm{n}-\mathrm{C}_{4}$ and $\mathrm{i}-\mathrm{C}_{4}$ ) was not significantly affected by cutting the $\mathrm{CO}_{2}$ dosage. Lowering the vitamin $\mathrm{B} 12$ concentration from 0.375 to $0.0125 \mathrm{mg} \mathrm{L}^{-1}$ in phase IV also did not significantly affect the overall performance of the reactor (Table 3). Confidence intervals of the conversion rates overlap for phases II and VI, where the only difference is the influent B12 concentration.

Batch Experiments Show That at pH 5.2 i- $\mathrm{C}_{4}$ Formation Is Caused by the Presence of $n-C_{4}$ and Vice Versa. The results of the first batch series are summarized in Figure 2. The concentration profiles and gas headspace partial pressures for each separate batch are given in 


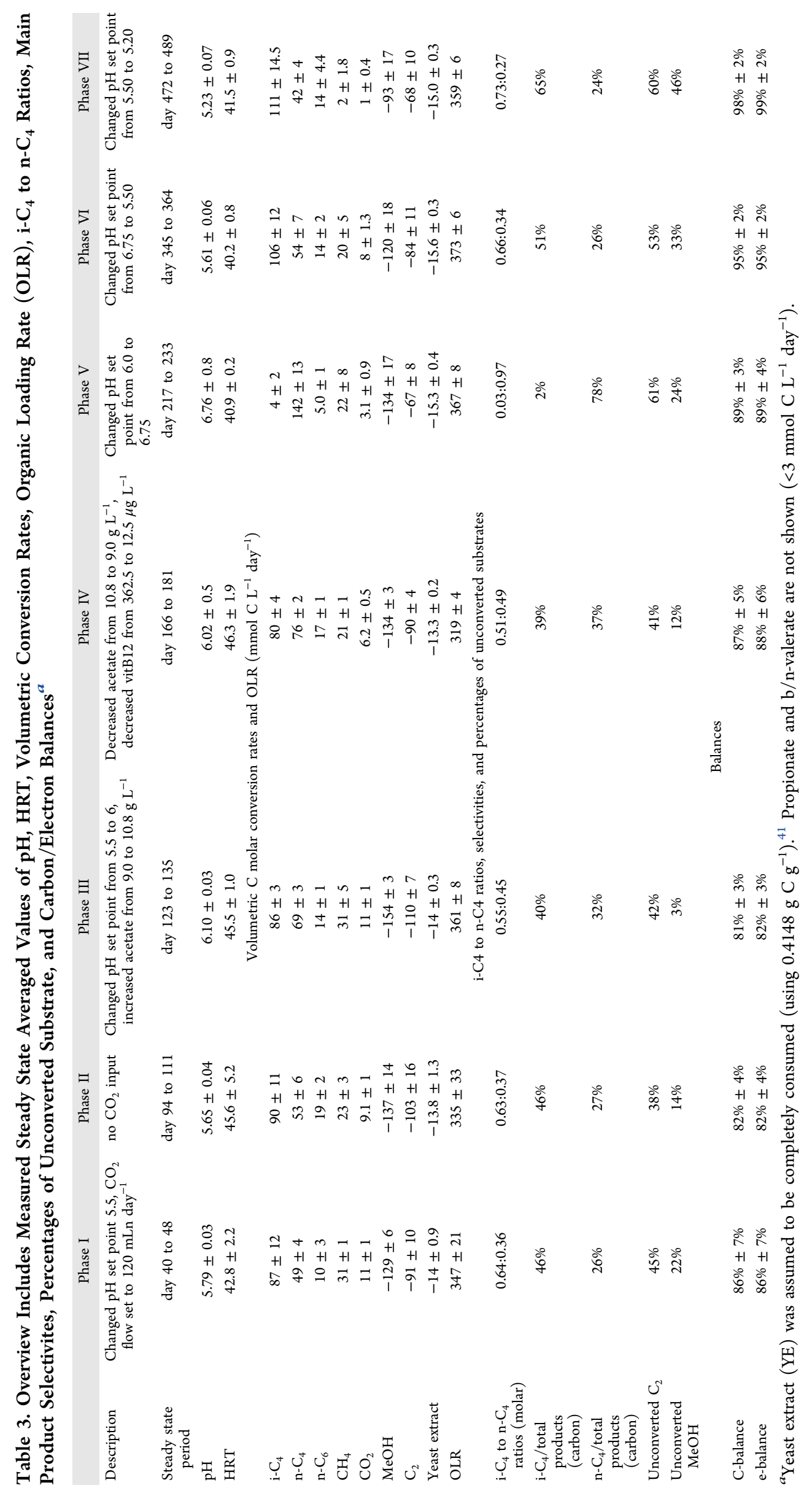




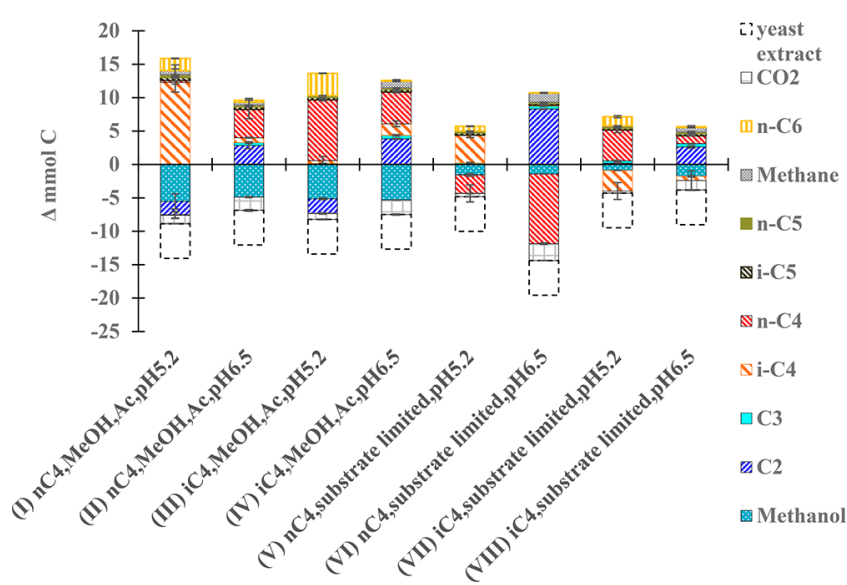

Figure 2. Formation and consumption of carbon-containing components during the batch experiments. Error bars show the difference between the duplicate experiments. The yeast extract that was added to the medium was assumed to be fully consumed. ${ }^{41}$ The total formation and consumption after 77 days are shown.

Figures S8 to S11 in the Supporting Information. The results show that at $\mathrm{pH}$ 5.2, $\mathrm{i}-\mathrm{C}_{4}$ formation is triggered by the presence of $n-C_{4}(I, V)$ and that $n-C_{4}$ formation is triggered by the presence of $\mathrm{i}_{-} \mathrm{C}_{4}$ (III, VII). Additionally, a $\mathrm{pH}$ of 5.2 induces $n-C_{6}$ formation, whereas at $\mathrm{pH} 6.5$, hardly any $\mathrm{n}-\mathrm{C}_{6}$ is formed. At $\mathrm{pH}$ 6.5, there is mainly acetate and $\mathrm{n}-\mathrm{C}_{4}$ formation from methanol and $\mathrm{CO}_{2}$ (II and IV).

In batches $\mathrm{V}$ to VIII, substrate was limited to the amount that came from the inoculum. Here, methanol was quickly consumed in three batches (V, VI, and VIII) and more slowly in the batch at $\mathrm{pH} 5.2$ with added $\mathrm{i}-\mathrm{C}_{4}$ (VII). The batch with added $\mathrm{n}-\mathrm{C}_{4}$ at $\mathrm{pH} 6.5$ (VI) showed significant $\mathrm{n}-\mathrm{C}_{4}$ consumption ( $45 \%$ of the supplied $n-C_{4}$ was consumed), and acetate was formed together with methane. In contrast, the batch with added $\mathrm{i}-\mathrm{C}_{4}$ at $\mathrm{pH} 6.5$ (VIII) showed very little $\mathrm{i}-\mathrm{C}_{4}$ degradation ( $\sim 98 \%$ remained) within the time frame of the experiment (77 days). The substrate-limited batches show that (de)isomerization occurred at $\mathrm{pH} 5.2$ (V, VII) as well as at $\mathrm{pH}$ 6.5 (VIII). However, the concentration profiles (Figure S9) of these batches show that (de)isomerization activity occurred only during chain elongation activity when methanol was present but not after methanol was depleted. This is emphasized by the calculated conversions that occurred after methanol was depleted (shown in Figure S7).

Determining That $\mathrm{i}-\mathrm{C}_{4}$ and $\mathrm{n}-\mathrm{C}_{4}$ Ratios Meet Thermodynamic Equilibrium of Isomerization. A second batch series was performed (A-M, Table 2) at $\mathrm{pH} 5.5$ to further investigate the impact of methanol, acetate, and $\mathrm{i}-\mathrm{C}_{4}$. Batches A-F started with different initial amounts of $\mathrm{i}-\mathrm{C}_{4}(0-$ $50 \mathrm{mM})$ and batches $\mathrm{G}-\mathrm{M}$ started with different initial amounts of acetate and methanol (50-300 mMC) at $t=0$. The results of each individual batch are shown in Figures S12S19 (concentration profiles, as well as headspace partial pressure profiles). All batches showed $\mathrm{i}-\mathrm{C}_{4}$ and $\mathrm{n}-\mathrm{C}_{4}$ formation from acetate and methanol with a similar pattern as during the first series: presence of initial $i-C_{4}(A-F)$ caused $n-C_{4}$ to be formed first, followed by simultaneous formation of both butyrate species. The results of batches $A-F$ and $G-M$ are summarized in Figure $3 \mathrm{~A}$ and $\mathrm{B}$, respectively, which show the ratios of $i-C_{4}$ and $n-C_{4}$ over total $C_{4}$ as measured during all batches throughout the operation period. In addition, a horizontal line is added to the figure that represents the ratio
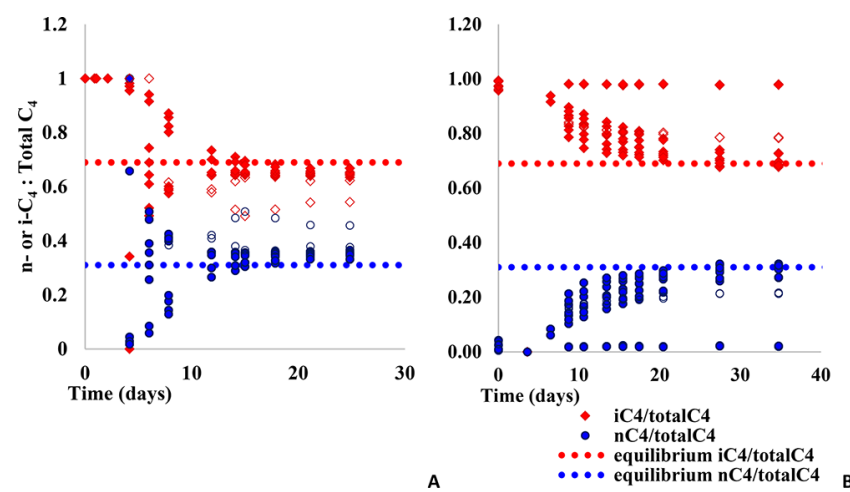

Figure 3. (A) (batches $\mathrm{A}-\mathrm{E}$, negative control $\mathrm{F}$ excluded) and (B) (batches $\mathrm{G}-\mathrm{L}$ ) show $\mathrm{i}-\mathrm{C}_{4}$ and $\mathrm{n}-\mathrm{C}_{4}$ to total $\mathrm{C}_{4}$ ratios as measured during all batches throughout the operation period. Dotted lines represent the calculated equilibrium ratio using an isomerization $\Delta G_{\mathrm{r}}$ of $-1.98 \mathrm{~kJ}^{42,43}$ The concentrations of $\mathrm{n}^{4} \mathrm{C}_{4}$ and $\mathrm{i}-\mathrm{C}_{4}$ are interdependent and approach a ratio that is determined by equilibrium of isomerization as the batches progress. In panel (A), the unfilled symbols represent the batch that was started without inoculum (but apparently was contaminated). In panel (B), the unfilled symbols represent the batch that started with $300 \mathrm{mMC}$ methanol, acetate, and $50 \mathrm{mM} \mathrm{i-} \mathrm{C}_{4}$. The two series are highlighted in this way because they show a deviating behavior compared to the other batches (not seeming to approach the calculated equilibrium ratios).

at isomerization equilibrium conditions, which is calculated as shown on pages S10 and S11 in the Supporting Information. Eventually the concentrations of the butyrate species seem to approach this equilibrium in most cases. The progress of $\mathrm{i}-\mathrm{C}_{4}$ and $n-C_{4}$ to total $C_{4}$ ratios in the continuous reactor system are shown in Figure $\mathrm{S} 6$ and follow the same relation when operated at low $\mathrm{pH}(5.2-5.5)$.

Microbial Community Analysis: Key Players in Reactor Are Related to Clostridium luticellari and Eubacterium limosum. The biomass from phases II, IV, V, VI, and VII of the continuous reactor, as well as biomass from batches I-VIII were harvested to be used for a 16s rRNA gene microbial community analysis. A heat map of the microbial community analysis data is shown in Table 4 (Table S7 in the Supporting Information shows the complete data). The results show that operating the reactor at increasing $\mathrm{pH}$ levels causes a gradual shift in Clostridiales composition from Clostridiaceae 1 (at $\mathrm{pH}$ 5.2) to Eubacteriaceae (at $\mathrm{pH}$ 6.75). The shift was reversed when reactor $\mathrm{pH}$ was decreased again. The batch experiments (I-VIII) that were inoculated with biomass from phase VII ( $\mathrm{pH}$ 5.2) show a selection toward different microbiomes at the end of the batch.

In the reactor at $\mathrm{pH} 6.75$, the most dominant genus is Eubacterium. The most abundant OTU (40\% relative abundance, Table S8) showed a slight similarity ( $94.8 \%$ identity, $100 \%$ query cover) with Eubacterium limosum. Operating the reactor at $\mathrm{pH} 5.2$ caused an apparent complete washout of the Eubacterium order and strictly selected for Clostridium sensu stricto 12 dominance. The most abundant Clostridium sensu stricto 12 OTU (Table S9) showed a very high similarity (99.7\% identity, $100 \%$ query cover) with Clostridium luticellarii.

The batch series showed a microbial selection that was similar to the selection in the continuous reactor to some extent. Clostridium luticellarii presence is maintained at $\mathrm{pH}$ 5.2, albeit at a lower relative abundance than within the continuous 
Table 4. Heat Map Showing Relative Abundances of All Orders and for Clostridiales also All Observed Genera

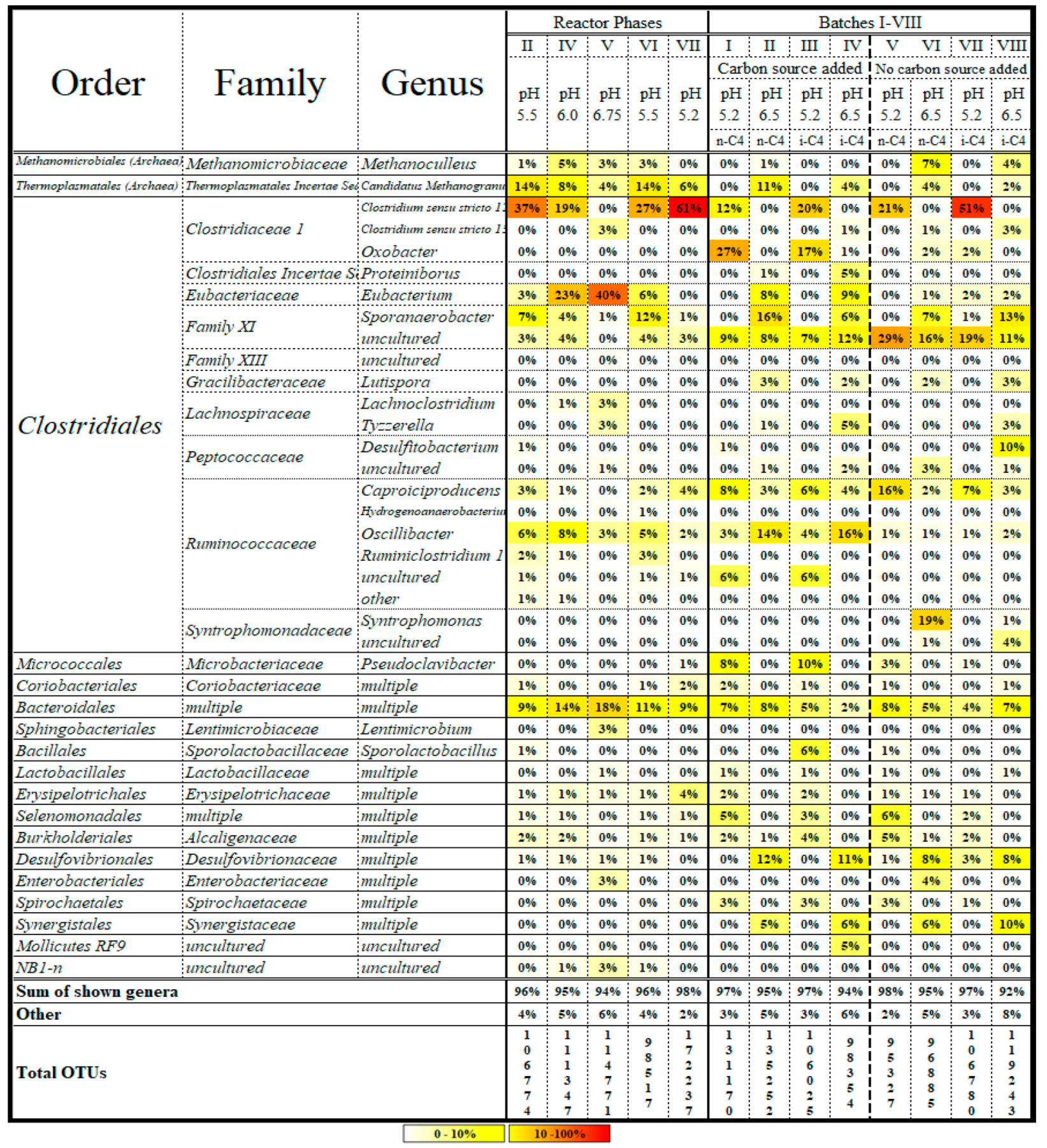

reactor. At $\mathrm{pH} 6.5$, the relative abundance of the Eubacterium order increased from $0 \%$ (phase VII used as inoculum) to $8 \%$ and $9 \%$ in batches II and IV, respectively. In addition to these microbes, a large amount of other Clostridiales emerged in the batches among which the most abundant were Oxobacter (at $\mathrm{pH}$ 5.2), Family XI, and Oscillibacter (at pH 6.5).

\section{DISCUSSION}

Methanol-Based Chain Elongation with Acetate to nButyrate and Isobutyrate at Varying (high) Selectivities Dependent on $\mathrm{pH}$. This study shows that the product spectrum of methanol-based chain elongation can be adjusted using $\mathrm{pH}$ as a selection pressure tool. $\mathrm{A} \mathrm{pH}$ of around 6.75 in the continuous reactor facilitated the dominance of an unknown Eubacterium that resembled Eubacterium limosum, which is a known methanol-based chain elongation microbe. ${ }^{35}$ The results suggest that the microbiome dominated by Eubacterium does not form isobutyrate $\left(\mathrm{i}-\mathrm{C}_{4}\right)$ under these conditions. A pure culture experiment with E. limosum done at $\mathrm{pH} 5.5$ also showed no i- $\mathrm{C}_{4}$ formation, only n-butyrate $\left(\mathrm{n}-\mathrm{C}_{4}\right)$ formation (Figure S20).

Lowering the $\mathrm{pH}$ in the reactor toward 5.5 changed the microbiome toward a state where a Clostridium luticellariirelated species was dominant. At this $\mathrm{pH}$, there was still a small amount of Eubacteria present (6\%) and more so in the sampled biofilm that had grown within the $\mathrm{pH}$ control volume (Figure 
S1 and Table S7). Further lowering the $\mathrm{pH}$ to 5.2 led to a steady state in phase VII without the Eubacterium genus ( $0 \%$ relative abundance) and with the OTU related to $C$. luticellarii at a $55.5 \%$ relative abundance. A pure culture of $C$. luticellarii has recently been shown to be able to form i- $C_{4}$ and $n-C_{4}$ under supplementation of acetate and methanol. ${ }^{44}$

Suppressing Methanogenesis at pH 5.2 Increased Chain Elongation Selectivity. Shifting the reactor $\mathrm{pH}$ from 5.5 to 5.2 significantly lowered methanogenic activity as well as the relative abundances of Archaea. The microbiome analysis showed two potential candidates for methanogenic activity: (i) hydrogenotrophic methanogenesis by the Methanoculleus genus (98.8\% identity, 99\% query cover, Methanoculleus palmolei DSM 4273), ${ }^{45}$ and (ii) methylotrophic methanogenesis by an unknown Candidatus methanogranum (closest similarity to Methanomassiliicoccus luminyensis, $87.76 \%$ identity, 99\% query cover). ${ }^{46,47}$ The decrease in methanogenic activity was simultaneous with a decrease in methanol consumption, suggesting that the observed methanogenesis at $\mathrm{pH} 5.5$ was of a methylotrophic nature. ${ }^{48}$ This shift from $\mathrm{pH} 5.5$ to 5.2 effectively lowered methanogenic activity, while maintaining chain elongation activity. Methylotrophic methanogenensis can occur down to $\mathrm{pH} 4.2 .{ }^{49}$ However, its inhibition is known to be amplified by high concentrations of undissociated acids ${ }^{26,50}$ and by sufficient mixing that prevents niche and biofilm formation. $^{51}$ As a result, total chain elongation selectivity increased from $84 \%$ to $96 \%$ (percentage of the summed formed $\mathrm{i}-\mathrm{C}_{4}, \mathrm{n}-\mathrm{C}_{4}$, and $\mathrm{n}-\mathrm{C}_{6}$ per total amount of formed products, based on carbon atoms). Overall, the selection pressure in the reactor was sufficient to select for methanolbased chain elongators and to prevent methanogenesis from becoming the dominant bioprocess.

$\mathrm{i}-\mathrm{C}_{4}$ and $\mathrm{n}-\mathrm{C}_{4}$ Ratios Meet Thermodynamic Equilibrium of Isomerization. In the continuous reactor experiment, the formation of $\mathrm{i}-\mathrm{C}_{4}$ and $\mathrm{n}-\mathrm{C}_{4}$ at $\mathrm{pH}$ 5.5, as well as at $\mathrm{pH} 5.2$, seemed to occur toward concentrations that approached the thermodynamic equilibrium of isomerization (Figure S6A and S6B). The batch series $\mathrm{A}-\mathrm{M}$ also showed i$\mathrm{C}_{4}$ and $\mathrm{n}-\mathrm{C}_{4}$ formation progressing toward a similar ratio, as well as a previous study on methanol-based chain elongation. ${ }^{23}$ Moreover, an experiment that was done with cell extracts and was designed to determine butyryl-CoA:isobutyryl-CoA mutase activity showed that in this setup isobutyryl-CoA to butyryl-CoA ratios approach a similar value. ${ }^{34}$ The genome of C. luticellarii (DSM 29923) has recently been sequenced and harbors genes encoding for enzymes within the isobutyryl-CoA mutase (ICM)-like subfamily (NCBI Reference Sequence: WP 106007777.1 and WP 106008210.1). ${ }^{52}$ In contrast, the sequences of two known Eübacterium limosum species (taxid: 1736 and 903814) do not contain any similarities to genes of the ICM-like subfamily (NCBI blastp queries with various fused isobutyryl-CoA mutases, icmF, show no similarity). On the basis of the stoichiometric and microbial analysis of this research and the work on pure C. luticellarii (DSM 29923), ${ }^{44}$ it is suggested that this species forms both $\mathrm{i}-\mathrm{C}_{4}$ and $\mathrm{n}-\mathrm{C}_{4}$ during methanol-based chain elongation of acetate coupled to a bidirectional isomerization reaction dictated by thermodynamic conditions. For this fermentation, $\mathrm{i}-\mathrm{C}_{4}$ and $\mathrm{n}-\mathrm{C}_{4}$ are effectively the main end products (apart from the formation of small $\mathrm{n}-\mathrm{C}_{6}$ amounts), which allows their ratios to approach thermodynamic equilibrium. In contrast, during other isobutyrate-forming fermentations, e.g., methanogenesis systems $^{30,31}$ and bioelectrochemical systems, ${ }^{15,16}$ the metabolic fluxes are also geared toward the formation of alternative products from butyrate as the intermediate, which could prevent equilibrium of isomerization from being established.

Isobutyrate Formation Was Observed to Be Coupled to Catabolic Activity of Methanol Chain Elongation at Low $\mathrm{pH}$. Isomerization of $\mathrm{n}-\mathrm{C}_{4}$ and $\mathrm{i}-\mathrm{C}_{4}$ can occur in both directions and is regularly observed within methanogenic cultures. ${ }^{34,53}$ Within methanogenic cultures, (de)isomerization of butyrate species is coupled to beta-oxidation and consecutive hydrogenotrophic and acetotrophic methanogenesis. $^{30,33}$ In this research, however, the microbiome performed methanol-based chain elongation, and methanogenesis was mainly methylotrophic. It took the microbiome 3 weeks in a batch (VI, at $\mathrm{pH}$ 6.5, Figure S9) to develop observable beta-oxidation activity, which shows this activity was negligible during continuous reactor operation. The increase in relative abundance of Syntrophomonas and Methanoculleus ${ }^{45,54}$ (Table 4, batch VI) supports this observation. Moreover, deisomerization of $\mathrm{i}-\mathrm{C}_{4}$ occurred slowly, if not at all (batches VII and VIII).

In the first batch series (I-VIII), which was done at low substrate concentrations, equilibrium of isomerization could not be achieved before the substrate was depleted; in the absence of methanol, catabolic activity (chain elongation) was halted and so was (de)isomerization activity. It shows that the $\mathrm{i}-\mathrm{C}_{4}$ formation is driven by the active formation of the butyrate species via methanol-based chain elongation. The enzyme butyryl-CoA:isobutyryl-CoA mutase that performs reversible isomerization requires activation of the substrates via a Coenzyme A bond. ${ }^{55}$ It is known that transition from exponential phase (during substrate abundance) to stationary phase (when energy sources become limited) can lead to drastic changes of the metabolic fluxes, ${ }^{56}$ accompanied by large changes in intracellular CoA-derivative concentrations. ${ }^{57,58}$ The metabolic changes during substrate limitation, combined with other regulatory mechanisms, ${ }^{59,60}$ could potentially have reduced the flux toward (de)isomerization and explain the lack of passive (de)isomerization. However, to experimentally verify this hypothesis, pure culture experiments with Clostridium luticellarii to determine intracellular concentrations and enzyme activity assays to determine $K_{\mathrm{m}}$ and $k_{\text {cat }}$ values would need to be performed.

Isomerization of $\mathrm{n}-\mathrm{C}_{4}$ to $\mathrm{i}-\mathrm{C}_{4}$ May Provide a Competitive Advantage to Chain Elongation Microbes at Low $\mathrm{pH}$ and a High Undissociated Acid Concentration. A physiological reason for $\mathrm{i}_{-} \mathrm{C}_{4}$ formation can be found in exploring what selection advantage is gained under the supplied conditions. Isobutyrate formation was stimulated in an environment with a high concentration of fatty acids and a $\mathrm{pH}$ that approaches the $\mathrm{p} K_{\mathrm{a}}$ values of these acids (see Figure S4 for the undissociated acids concentration in the reactor). It is known that branched fatty acids have a lower toxic effect on microorganisms than unbranched forms. ${ }^{61}$ Partly, this can be explained because $\mathrm{i}-\mathrm{C}_{4}$ is predicted to have a lower diffusivity through cellular membranes compared to $\mathrm{n}-\mathrm{C}_{4}{ }^{62}$ thereby lessening the strain on maintenance due to futile cycling. ${ }^{26}$ Thus, hypothetically, switching toward an $\mathrm{i}-\mathrm{C}_{4}$ forming catabolism could give a competitive advantage to the chain elongation microbe that is growing at low $\mathrm{pH}$ and at high undissociated acid concentrations. This would explain the dominance of $\mathrm{i}-\mathrm{C}_{4}$ formation at the lower applied $\mathrm{pH}$, and its absence at a higher $\mathrm{pH}$ where an anabolic investment of 
making an additional enzyme by organisms to perform the isomerization is not energetically rewarded.

Future Outlook. During the last phase (VII, at $\mathrm{pH}$ 5.2) of the reactor, the highest $\mathrm{i}-\mathrm{C}_{4}$ volumetric productivity was $111 \pm$ $15 \mathrm{mmol} \mathrm{C} \mathrm{L}^{-1}$ day $^{-1}$ or $2.4 \pm 0.3 \mathrm{~g} \mathrm{~L}^{-1}$ day $^{-1}$ with an average broth concentration of $191 \pm 28 \mathrm{mM} \mathrm{C}$ or $4.2 \pm 0.6 \mathrm{~g} \mathrm{~L}^{-1}$ and a selectivity toward $\mathrm{i}-\mathrm{C}_{4}$ of 0.65 carbon per carbon of total products. The achieved volumetric productivity was $20 \%$ higher (continuous reactor), and the achieved concentration was $80 \%$ higher (batch) than in an earlier study on $\mathrm{i}-\mathrm{C}_{4}$ formation via methanol-based chain elongation. ${ }^{13}$ The batch experiments showed i- $\mathrm{C}_{4}$ production up to a concentration of around $400 \mathrm{mM} \mathrm{C}, 8.8 \mathrm{~g} \mathrm{~L}^{-1}$ (and $\mathrm{n}-\mathrm{C}_{4}$ up to a concentration of around $150 \mathrm{mM} \mathrm{C}, 3.3 \mathrm{~g} \mathrm{~L}^{-1}$ ), where chain elongation became constrained despite acetate and methanol still being available. It shows the limitations of methanol-based chain elongation in the batch set up but also that a higher broth concentration within the continuous system can likely be achieved. The necessary increased productivity may be reached by an increase in the amount of active biomass via biomass retention with, for example, granulation techniques. ${ }^{63,64}$ Further exploring the metabolic pathway(s) and investigating the potential physiological reasons for $\mathrm{i}-\mathrm{C}_{4}$ formation may also give more insight in the fundamental principles that drive the selection of the developed reactor microbiome. Finally, more researches on effective product recovery methods and specific case-tailored solutions are necessary to determine how valorization of organic residues by chain elongation can become economically feasible. ${ }^{65}$

\section{ASSOCIATED CONTENT}

\section{SI Supporting Information}

The Supporting Information is available free of charge at https://pubs.acs.org/doi/10.1021/acssuschemeng.0c00907.

Additional information regarding Materials and Methods and additional figures and graphs for the Results and Discussion, 22 figures, and 13 tables (PDF)

\section{Accession Codes}

All data generated or analyzed during this study are included in this published article (and the Supporting Information). Microbiota data (raw 16s rRNA gene amplicon sequences) are submitted to the EBI database (https://www.ebi.ac.uk/ ena) under accession number PRJEB36205.

\section{AUTHOR INFORMATION}

\section{Corresponding Author}

David P. B. T. B. Strik - Environmental Technology, Wageningen University \& Research, 6708WG Wageningen, The

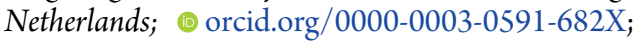
Phone: +31 317483 447; Email: david.strik@wur.nl

\section{Authors}

Kasper D. de Leeuw - Environmental Technology, Wageningen University \& Research, 6708WG Wageningen, The Netherlands; 0 orcid.org/0000-0001-8145-2604

Sanne M. de Smit - Environmental Technology, Wageningen University \& Research, 6708WG Wageningen, The Netherlands

Sabine van Oossanen - Environmental Technology, Wageningen University \& Research, 6708WG Wageningen, The Netherlands
Marinus J. Moerland - Environmental Technology, Wageningen University \& Research, 6708WG Wageningen, The

Netherlands; (1) orcid.org/0000-0002-2174-7168

Cees J. N. Buisman - Environmental Technology, Wageningen University \& Research, 6708WG Wageningen, The Netherlands

Complete contact information is available at:

https://pubs.acs.org/10.1021/acssuschemeng.0c00907

\section{Author Contributions}

K.D.d.L. planned and performed the continuous reactor experiment, planned and helped executed the batch experiments, analyzed the results, and wrote the manuscript. S.M.d.S. contributed to the experimental design of the first batch series, its execution, data interpretation, drafted the results sections, and revised the manuscript. S.v.O. contributed to the experimental design of the second batch series, its execution, data interpretation, drafted the results sections, and revised the manuscript. M.J.M. contributed with many preliminary batch experiments that led to the design of this research, among which the pure EL culture batch. He helped with the data interpretation and revised the manuscript. C.J.N.B. participated as a coapplicant of the ALWGR.2015.8 project and planning of the study, contributed to the experimental design and data interpretation, and revised the manuscript. D.P.B.T.B.S. is principal investigator and designer of the ALWGR.2015.8 project, secured project funding, planned the study, contributed to the experimental design and data interpretation, and revised the manuscript. All authors have read and approved the final manuscript.

Notes

The authors declare no competing financial interest.

\section{ACKNOWLEDGMENTS}

We thank ChainCraft B.V. for their help in carrying out the research. We thank The Netherlands Organisation for Scientific Research (NWO) for providing financial support. This research was carried out with help of ChainCraft B.V. and a grant from The Netherlands Organisation for Scientific Research (NWO), Project Number ALWGR.2015.8.

\section{ABBREVIATIONS}

SCCs $=$ short chain carboxylates

MCCs = medium chain carboxylates

$\mathrm{C}_{2}=$ acetate

$\mathrm{C}_{3}=$ propionate

$\mathrm{n}-\mathrm{C}_{4}=$ n-butyrate

i- $\mathrm{C}_{4}=$ isobutyrate

$\mathrm{n}-\mathrm{C}_{6}=$ caproate

$\mathrm{YE}=$ yeast extract

HRT = hydraulic retention time

OTU = operational taxonomic unit

$\mathrm{MeOH}=$ methanol

\section{REFERENCES}

(1) Di Maio, F.; Rem, P. C.; Baldé, K.; Polder, M. Measuring resource efficiency and circular economy: A market value approach. Resources, Conservation and Recycling 2017, 122, 163-171.

(2) Saswattecha, K.; Kroeze, C.; Jawjit, W.; Hein, L. Assessing the environmental impact of palm oil produced in Thailand. J. Cleaner Prod. 2015, 100, 150-169.

(3) Bagby, M. O.; Johnson, R. W., Jr.; Daniels, R. W.; Contrell, R. R.; Sauer, E. T.; Keenan, M. J.; Krevalis, M. A. Carboxylic Acids; John 
Wiley \& Sons, Inc., 2003.

D O I : $10.1002 /$ 0471238961.1921182202010702.a01.pub2.

(4) Angenent, L. T.; Richter, H.; Buckel, W.; Spirito, C. M.; Steinbusch, K. J. J.; Plugge, C. M.; Strik, D. P. B. T. B.; Grootscholten, T. I. M.; Buisman, C. J. N.; Hamelers, H. V. M. Chain Elongation with Reactor Microbiomes: Open-Culture Biotechnology To Produce Biochemicals. Environ. Sci. Technol. 2016, 50 (6), 2796-2810.

(5) Agler, M. T.; Wrenn, B. A.; Zinder, S. H.; Angenent, L. T. Waste to bioproduct conversion with undefined mixed cultures: the carboxylate platform. Trends Biotechnol. 2011, 29 (2), 70-78.

(6) De Groof, V.; Coma, M.; Arnot, T.; Leak, D. J.; Lanham, A. B. Medium Chain Carboxylic Acids from Complex Organic Feedstocks by Mixed Culture Fermentation. Molecules 2019, 24 (3), 398.

(7) Steinbusch, K. J.; Hamelers, H. V.; Plugge, C. M.; Buisman, C. J. Biological formation of caproate and caprylate from acetate: fuel and chemical production from low grade biomass. Energy Environ. Sci. 2011, 4 (1), 216-224.

(8) Han, W.; He, P.; Shao, L.; Lü, F. Road to full bioconversion of biowaste to biochemicals centering on chain elongation: A mini review. J. Environ. Sci. (Beijing, China) 2019, 86, 50-64.

(9) Chen, W. S.; Ye, Y.; Steinbusch, K. J. J.; Strik, D. P. B. T. B.; Buisman, C. J. N. Methanol as an alternative electron donor in chain elongation for butyrate and caproate formation. Biomass Bioenergy 2016, 93, 201-208.

(10) Yang, D.; Zhu, Q.; Chen, C.; Liu, H.; Liu, Z.; Zhao, Z.; Zhang, X.; Liu, S.; Han, B. Selective electroreduction of carbon dioxide to methanol on copper selenide nanocatalysts. Nat. Commun. 2019, 10 (1), 677.

(11) Demirbas, A. Biomethanol Production from Organic Waste Materials. Energy Sources, Part A 2008, 30 (6), 565-572.

(12) Balan, V.; Chiaramonti, D.; Kumar, S. Review of US and EU initiatives toward development, demonstration, and commercialization of lignocellulosic biofuels. Biofuels, Bioprod. Biorefin. 2013, 7 (6), $732-759$.

(13) Chen, W.-S.; Huang, S.; Strik, D. P.; Buisman, C. J. N. Isobutyrate biosynthesis via methanol chain elongation: converting organic wastes to platform chemicals. J. Chem. Technol. Biotechnol. 2017, 92 (6), 1370-1379.

(14) Chen, W.-S.; Huang, S.; Plugge, C. M.; Buisman, C. J. N.; Strik, D. P. B. T. B. Concurrent use of methanol and ethanol for chainelongating short chain fatty acids into caproate and isobutyrate. $J$. Environ. Manage. 2020, 258, 110008.

(15) Vassilev, I.; Hernandez, P. A.; Batlle-Vilanova, P.; Freguia, S.; Krömer, J. O.; Keller, J.; Ledezma, P.; Virdis, B. Microbial Electrosynthesis of Isobutyric, Butyric, Caproic Acids, and Corresponding Alcohols from Carbon Dioxide. ACS Sustainable Chem. Eng. 2018, 6 (7), 8485-8493.

(16) Vassilev, I.; Kracke, F.; Freguia, S.; Keller, J.; Krömer, J. O.; Ledezma, P.; Virdis, B. Microbial electrosynthesis system with dual biocathode arrangement for simultaneous acetogenesis, solventogenesis and carbon chain elongation. Chem. Commun. 2019, 55 (30), 4351-4354.

(17) Zhang, K.; Woodruff, A. P.; Xiong, M.; Zhou, J.; Dhande, Y. K. A Synthetic Metabolic Pathway for Production of the Platform Chemical Isobutyric Acid. ChemSusChem 2011, 4 (8), 1068-1070.

(18) Lang, K.; Zierow, J.; Buehler, K.; Schmid, A. Metabolic engineering of Pseudomonas sp. strain VLB120 as platform biocatalyst for the production of isobutyric acid and other secondary metabolites. Microb. Cell Fact. 2014, 13, 2-2.

(19) Ruppert, W.; Siegert, H.-J., Method for Making Isobutyric Acid. U.S. Patent US4452999A, 1993.

(20) Zhang, Z. C.; Dery, M.; Zhang, S.; Steichen, D. New process for the production of branched-chain fatty acids. J. Surfactants Deterg. 2004, 7 (3), 211-215.

(21) Perez, J. M.; Richter, H.; Loftus, S. E.; Angenent, L. T. Biocatalytic reduction of short-chain carboxylic acids into their corresponding alcohols with syngas fermentation. Biotechnol. Bioeng. 2013, 110 (4), 1066-1077.
(22) Kleerebezem, R.; van Loosdrecht, M. C. M. Mixed culture biotechnology for bioenergy production. Curr. Opin. Biotechnol. 2007, 18 (3), 207-212.

(23) de Smit, S. M.; de Leeuw, K. D.; Buisman, C. J. N.; Strik, D. P. B. T. B. Continuous $n$-valerate formation from propionate and methanol in an anaerobic chain elongation open-culture bioreactor. Biotechnol. Biofuels 2019, 12 (1), 132.

(24) Lindley, N. D.; Loubière, P.; Pacaud, S.; Mariotto, C.; Goma, G. Novel Products of the Acidogenic Fermentation of Methanol during Growth of Eubacterium limosum in the Presence of High Concentrations of Organic Acids. Microbiology 1987, 133 (12), $3557-3563$.

(25) Rodríguez, J.; Lema, J. M.; Kleerebezem, R. Energy-based models for environmental biotechnology. Trends Biotechnol. 2008, 26 (7), 366-374.

(26) Infantes, D.; González del Campo, A.; Villaseñor, J.; Fernández, F. J. Kinetic model and study of the influence of $\mathrm{pH}$, temperature and undissociated acids on acidogenic fermentation. Biochem. Eng. J. 2012, $66,66-72$.

(27) Phillips, J. R.; Klasson, K. T.; Clausen, E. C.; Gaddy, J. L. Biological production of ethanol from coal synthesis gas - Medium development studies. Appl. Biochem. Biotechnol. 1993, 39-40 (1), 559-571.

(28) de Leeuw, K.; Buisman, C. J.; Strik, D. P. Branched Medium Chain Fatty Acids: iso-caproate formation from iso-butyrate broadens the product spectrum for microbial chain elongation. Environ. Sci. Technol. 2019, 53 (13), 7704-7713.

(29) Cresson, R.; Escudié, R.; Steyer, J.-P.; Delgenès, J.-P.; Bernet, N. Competition between planktonic and fixed microorganisms during the start-up of methanogenic biofilm reactors. Water Res. 2008, 42 (3), 792-800.

(30) Angelidaki, I.; Ahring, B. K. Isomerization of n- and i-butyrate in anaerobic methanogenic systems. Antonie van Leeuwenhoek 1995, 68 (4), 285-291.

(31) Tholozan, J.-L.; Samain, E.; Grivet, J.-P. Isomerization between n-butyrate and isobutyrate in enrichment cultures. FEMS Microbiol. Lett. 1988, 53 (3-4), 187-191.

(32) Oude Elferink, S. J. W. H.; Lens, P. N. L.; Dijkema, C.; Stams, A. J. M. Isomerization of butyrate to isobutyrate by Desulforhabdus amnigenus. FEMS Microbiol. Lett. 1996, 142 (2), 237-241.

(33) Wu, W.-M.; Jain, M. K.; Zeikus, J. G. Anaerobic Degradation of Normal- and Branched-Chain Fatty Acids with Four or More Carbons to Methane by a Syntrophic Methanogenic Triculture. Appl. Environ. Microbiol. 1994, 60 (7), 2220-2226.

(34) Matthies, C.; Schink, B. Reciprocal Isomerization of Butyrate and Isobutyrate by the Strictly Anaerobic Bacterium Strain WoG13 and Methanogenic Isobutyrate Degradation by a Defined Triculture. Appl. Environ. Microbiol. 1992, 58 (5), 1435-1439.

(35) Pacaud, S.; Loubière, P.; Goma, G.; Lindley, N. D. Organic acid production during methylotrophic growth of Eubacterium limosum B2: displacement towards increased butyric acid yields by supplementing with acetate. Appl. Microbiol. Biotechnol. 1986, 23 (5), 330-335.

(36) Jourdin, L.; Raes, S. M.; Buisman, C. J.; Strik, D. P. Critical biofilm growth throughout unmodified carbon felts allows continuous bioelectrochemical chain elongation from $\mathrm{CO} 2$ up to caproate at high current density. Front. Energy Res. 2018, 6, 7.

(37) Takahashi, S.; Tomita, J.; Nishioka, K.; Hisada, T.; Nishijima, M. Development of a Prokaryotic Universal Primer for Simultaneous Analysis of Bacteria and Archaea Using Next-Generation Sequencing. PLoS One 2014, 9 (8), e105592.

(38) Caporaso, J. G.; Kuczynski, J.; Stombaugh, J.; Bittinger, K.; Bushman, F. D.; Costello, E. K.; Fierer, N.; Peña, A. G.; Goodrich, J. K.; Gordon, J. I.; Huttley, G. A.; Kelley, S. T.; Knights, D.; Koenig, J. E.; Ley, R. E.; Lozupone, C. A.; McDonald, D.; Muegge, B. D.; Pirrung, M.; Reeder, J.; Sevinsky, J. R.; Turnbaugh, P. J.; Walters, W. A.; Widmann, J.; Yatsunenko, T.; Zaneveld, J.; Knight, R. QIIME allows analysis of high-throughput community sequencing data. Nat. Methods 2010, 7 (5), 335-336. 
(39) Quast, C.; Pruesse, E.; Yilmaz, P.; Gerken, J.; Schweer, T.; Yarza, P.; Peplies, J.; Glöckner, F. O. The SILVA ribosomal RNA gene database project: improved data processing and web-based tools. Nucleic Acids Res. 2013, 41, D590-D596.

(40) Edgar, R. C. Search and clustering orders of magnitude faster than BLAST. Bioinformatics 2010, 26 (19), 2460-2461.

(41) Duboc, P.; Schill, N.; Menoud, L.; Van Gulik, W.; Von Stockar, $\mathrm{U}$. Measurements of sulfur, phosphorus and other ions in microbial biomass: influence on correct determination of elemental composition and degree of reduction. J. Biotechnol. 1995, 43 (2), 145-158.

(42) Yu, H.-Q.; Mu, Y.; Fang, H. H. P. Thermodynamic analysis of product formation in mesophilic acidogenesis of lactose. Biotechnol. Bioeng. 2004, 87 (7), 813-822.

(43) Kleerebezem, R.; Van Loosdrecht, M. C. M. A Generalized Method for Thermodynamic State Analysis of Environmental Systems. Crit. Rev. Environ. Sci. Technol. 2010, 40 (1), 1-54.

(44) Van Brabant, P.; Ganigué, R.; Rabaey, K. Understanding BioIsomerisation during Methanol Fermentation. M.Sc. Thesis, Universiteit Gent, 2019; Catalog number: rug01:002785053.

(45) Zellner, G.; Messner, P.; Winter, J.; Stackebrandt, E. Methanoculleus palmolei sp. nov., an irregularly coccoid methanogen from an anaerobic digester treating wastewater of a palm oil plant in North-Sumatra, Indonesia. Int. J. Syst. Bacteriol. 1998, 48 (4), 11111117.

(46) Iino, T.; Tamaki, H.; Tamazawa, S.; Ueno, Y.; Ohkuma, M.; Suzuki, K.-i.; Igarashi, Y.; Haruta, S. Candidatus Methanogranum caenicola: a Novel Methanogen from the Anaerobic Digested Sludge, and Proposal of Methanomassiliicoccaceae fam. nov. and Methanomassiliicoccales ord. nov., for a Methanogenic Lineage of the Class Thermoplasmata. Microbes Environ 2013, 28 (2), 244-250.

(47) Kröninger, L.; Gottschling, J.; Deppenmeier, U. Growth Characteristics of Methanomassiliicoccus luminyensis and Expression of Methyltransferase Encoding Genes. Archaea 2017, 2017, 2756573.

(48) Florencio, L. Fate of Methanol in Anaerobic Bioreactors. Ph.D. Thesis, Wageningen University \& Research, 1994; http://edepot.wur. $\mathrm{nl} / 206840$ (accessed May 2020).

(49) Florencio, L.; Nozhevnikova, A.; van Langerak, A.; Stams, A. J. M.; Field, J. A.; Lettinga, G. Acidophilic degradation of methanol by a methanogenic enrichment culture. FEMS Microbiol. Lett. 1993, 109 (1), 1-6.

(50) Florencio, L.; Field, J. A.; Lettinga, G. High-rate anaerobic treatment of alcoholic wastewaters. Braz. J. Chem. Eng. 1997, 14 (4), 409-416.

(51) Staley, B. F.; de Los Reyes, F. L., 3rd; Barlaz, M. A. Effect of spatial differences in microbial activity, $\mathrm{pH}$, and substrate levels on methanogenesis initiation in refuse. Appl. Environ. Microbiol. 2011, 77 (7), 2381-2391.

(52) Poehlein, A.; Bremekamp, R.; Lutz, V. T.; Schulz, L. M.; Daniel, R. Draft Genome Sequence of the Butanoic Acid-Producing Bacterium Clostridium luticellarii DSM 29923, Used for Strong Aromatic Chinese Liquor Production. Genome Announc. 2018, 6 (18), e00377-18.

(53) Wu, W.-M.; Jain, M. K.; Hickey, R. F.; Zeikus, J. G. Perturbation of syntrophic isobutyrate and butyrate degradation with formate and hydrogen. Biotechnol. Bioeng. 1996, 52 (3), 404411.

(54) Sousa, D. Z.; Smidt, H.; Alves, M. M.; Stams, A. J. M. Syntrophomonas zehnderi sp. nov., an anaerobe that degrades longchain fatty acids in co-culture with Methanobacterium formicicum. Int. J. Syst. Evol. Microbiol. 2007, 57 (3), 609-615.

(55) Narihiro, T.; Nobu, M. K.; Tamaki, H.; Kamagata, Y.; Sekiguchi, Y.; Liu, W.-T. Comparative Genomics of Syntrophic Branched-Chain Fatty Acid Degrading Bacteria. Microbes Environ 2016, 31 (3), 288-292.

(56) Amador-Noguez, D.; Brasg, I. A.; Feng, X.-J.; Roquet, N.; Rabinowitz, J. D. Metabolome Remodeling during the AcidogenicSolventogenic Transition in Clostridium acetobutylicum. Appl. Environ. Microbiol. 2011, 77 (22), 7984-7997.
(57) Chohnan, S.; Furukawa, H.; Fujio, T.; Nishihara, H.; Takamura, Y. Changes in the size and composition of intracellular pools of nonesterified coenzyme A and coenzyme A thioesters in aerobic and facultatively anaerobic bacteria. Applied and environmental microbiology 1997, 63 (2), 553-560.

(58) Vadali, R. V.; Bennett, G. N.; San, K.-Y. Cofactor engineering of intracellular $\mathrm{CoA} /$ acetyl-CoA and its effect on metabolic flux redistribution in Escherichia coli. Metab. Eng. 2004, 6 (2), 133-139.

(59) Wiesenborn, D. P.; Rudolph, F. B.; Papoutsakis, E. T. Coenzyme A transferase from Clostridium acetobutylicum ATCC 824 and its role in the uptake of acids. Appl. Environ. Microbiol. 1989, $55(2), 323-329$.

(60) Cracan, V.; Padovani, D.; Banerjee, R. IcmF Is a Fusion between the Radical B 12 Enzyme Isobutyryl-CoA Mutase and Its Gprotein Chaperone. J. Biol. Chem. 2010, 285, 655-66.

(61) Wilbanks, B.; Trinh, C. T. Comprehensive characterization of toxicity of fermentative metabolites on microbial growth. Biotechnol. Biofuels 2017, 10 (1), 262.

(62) Xiang, T.-X.; Anderson, B. D. Influence of Chain Ordering on the Selectivity of Dipalmitoylphosphatidylcholine Bilayer Membranes for Permeant Size and Shape. Biophys. J. 1998, 75 (6), 2658-2671.

(63) Roghair, M.; Strik, D. P. B. T. B.; Steinbusch, K. J. J.; Weusthuis, R. A.; Bruins, M. E.; Buisman, C. J. N. Granular sludge formation and characterization in a chain elongation process. Process Biochem. 2016, 51 (10), 1594-1598.

(64) Tamis, J.; Joosse, B. M.; Loosdrecht, M. C. M. v.; Kleerebezem, R. High-rate volatile fatty acid (VFA) production by a granular sludge process at low pH. Biotechnol. Bioeng. 2015, 112 (11), 2248-2255.

(65) Atasoy, M.; Owusu-Agyeman, I.; Plaza, E.; Cetecioglu, Z. Biobased volatile fatty acid production and recovery from waste streams: Current status and future challenges. Bioresour. Technol. 2018, 268, 773-786. 